\title{
The Use of Social Media as Learning Resources to Support the New Normal
}

\author{
Zahid Zufar At Thaariq, ${ }^{1}$ \\ zahid.thoriq.1701216@students.um.ac.id
}

\begin{abstract}
This article aims to study the use of social media as a learning resource. Basically, social media tends to be freely used by various circles, both in terms of cost and time spent. In addition, looking at the economic conditions during the declining COVID-19 pandemic, making social media can be used as an alternative step to learning resources compared to other learning application platforms that tend to be paid. Based on these facts, the authors are interested in studying social media's use as an alternative learning resource in favor of the New Normal policy that the government has now applied. One of New Normal policies decided by the government is to optimize the process of blended learning or full online in the implementation of education at every level. Thus, social media can be used to learn because of the simple process that makes it easier to learn in its use. There have been many studies that reveal the success of social media use, especially Youtube, Instagram, and WhatsApp, as learning resources before the pandemic so that social media can be used as a learning resource during New Normal life. Hopefully, through social media, this can be one of the alternative troubleshooting learning problems in the New Normal period.
\end{abstract}

Keywords: $\quad$ Social Media, Learning Resource, New Normal

Abstrak: $\quad$ Tulisan ini bertujuan untuk menelaah penggunaan media sosial sebagai sumber belajar. Pada dasarnya, media sosial cenderung bebas digunakan oleh berbagai kalangan, baik dari segi biaya maupun waktu yang digunakan. Di samping itu, melihat kondisi perekonomian selama masa pandemi COVID-19 yang semakin menurun menjadikan media sosial dapat digunakan sebagai langkah alternatif sumber belajar dibandingkan dengan platform aplikasi belajar lainnya yang cenderung berbayar. Dengan berdasarkan fakta tersebut, penulis tertarik untuk menelaah penggunaan media sosial sebagai sumber belajar alternatif dalam mendukung kebijakan New Normal yang kini telah diterapkan pemerintah. Salah satu kebijakan New Normal yang diputuskan pemerintah adalah mengoptimasi proses blended learning atau full online dalam pelaksanaan pendidikan di setiap jenjang. Maka, media sosial dapat digunakan untuk belajar karena prosesnya yang sederhana sehingga memudahkan pebelajar dalam penggunaannya. Telah banyak penelitian yang mengungkapkan keberhasilan penggunaan media sosial, khususnya Youtube, Instagram dan WhatsApp sebagai sumber belajar sebelum terjadinya pandemi, sehingga media sosial dapat digunakan sebagai sumber belajar saat berlangsungnya kehidupan New Normal. Harapannya melalui media sosial ini dapat menjadi salah satu alternatif pemecahan masalah belajar pada masa New Normal.

Kata Kunci: $\quad$ Media Sosial, Sumber Belajar, New Normal

Submitted: May $2020 \quad$ Reviewed: July 2020 Accepted: August 2020 Published:September 2020



OVID-19 has given a significant impact on various aspects of life. To date, as of June 14, 2020 , there have been 38,227 positive confirmed cases, with 14,531 cases were recovered and 2,134 death cases (Wikipedia, 2020). It still entails the potential for new cases. As the prevention, the government has decided on a policy of Large Scale Social Restrictions (Pembatasan Sosial Bersekala Besar/PSBB) in some areas that are categorized as the red or black zone. This policy certainly affects aspects of life support, especially economic growth. Since all sectors of the community's income are managed from home, it causes various problems. For example, based on data from the Ministry of Manpower, as many as 3.05 million employers in Indonesia were laid off (Putri, 2020). Even an estimated 5.23 million people will become unemployed. This phenomenon will undoubtedly affect the income that will get worsened.

To restore the economic sector, the government decided to implement a new policy. Because the world of work may not be forever limited, the economy must continue to operate, for this reason after the implementation of the PSBB with the ongoing COVID-19 pandemic, the government is seeking a new policy that seeks to restore the situation (New Normal) (Ministry of Health, 2020). This policy emphasizes the reopening of initially closed activities during the PSBB period, but with the applicable health protocol in accordance with the guidelines issued by the Ministry of Health in its regulations.

The New Normal policy affects not only the economy but also education. The learning process is optimized through online, making it possible for blended learning or full-online to occur. A broadcast of the Ministry of Education and Culture explained that the red, yellow, and orange zones (94 percent) are prohibited from the face-to-face learning process. The green zone ( 6 percent) has been allowed to carry out face-to-face learning process (Ministry of Education and Culture, 2020). Thus given to these states, an adaptive learning resource for students is required. It occurs due to the economic slowdown and declining income, which have become real reasons for the need for learning resources.

Fundamentally, learning resources are the foundation of knowledge in learning. In this era of efficiency, learning resources are very abundant and easily found. The internet is one of the learning resources that is inseparable from the search for knowledge (Lau et al., 2018). Consequently, it creates a change in learning resources that used to be physical forms, such as books, magazines, and others, to become non-physical, such as internet, applications, and, most importantly, social media (Kilpatrick, Sengchanh, Namvongsa, \& Gray, 2019). The current technological developments induce the emergence of e-learning which can be perceived as an innovative approach to providing a well-designed learning environment, student-centered, interactive, and accessible to anyone, anywhere, anytime by utilizing various attributes and digital technology resources together with other forms of learning materials suitable to be discovered, flexible and well-distributed learning environments (Khan, 2005). Hence, according to Karampiperis \& Sampson (2020), the selection and the sequence of adaptive learning resources are acknowledged as one of the most interesting research questions.

Various online learning tools have been developed before the COVID-19 outbreak. In various studies, numerous ICT-based learning tools and methods have been probed to support learning developers in planning and implementing learning systems (Paquette, 2014; Praherdhiono dkk., 2019; Suparti, Juliardi, Rafsanjani, \& Praherdhiono, 2018; Susilaningsih, Praherdhiono, Adi, \& Nindigraha, 2018). Distance learning has a two-century history (Jonassen et al., 2008), and that period was a significant change in how learning took place and was communicated (Moore, Dickson-Deane, \& Galyen, 2011). Social media is a form of ICT development (Setiawan \& Santoso, 2015).

Social media can be a source of advanced adaptive learning (Greenhow \& Robelia, 2009). Since social media facilitates to be accessed anywhere, anytime, and by anyone connected. It makes it easier for users to use it (Surahman et al., 2020). Besides, social media is a media that can be accessed freely 
by all ages, thus attracting people's interest to use it. Given the freedom and tranquility it possesses, social media has a significant impact in this modern world (Allcott, Braghieri, Eichmeyer, \& Gentzkow, 2019). These reasons have allowed technology to bridge obstacles between students and teachers, create a more informal, collegial, and interactive learning environment (Bozarth, 2010). Particularly in the current era of internet sophistication, it is easier for individuals to communicate freely (Biagi, 2012). The emergence of social media changes judgments about organizations produced and disseminated in the public domain into new information for the community (Etter, Ravasi, \& Colleoni, 2019).

Given the fast flow of information, a new generation will be born. The next generation will come with networking and multi-processing skills and global minds that their parents will never have imagined. Constant experience of youths in the networking milieu has left a profound impact on their approach to problem-solving and collaboration (Bingham \& Conner, 2010). It happens because they have become more adaptive to absorb existing information.

The use of social media as a learning resource is deemed necessary because according to the data from the Indonesian Internet Service Provider Association (Asosiasi Penyelenggara Jasa Internet Indonesial APJII) revealed that of 270 million Indonesian people (Gischa, 2020), 171 million people (Pratomo, 2019) or approximately 15 percent are internet users. APJII recorded the highest penetration was from the age of $15-19$ years by $91 \%$. The available information can be broadcasted via social media (WhatsApp, Instagram, YouTube, and others) (Aran, Biel, \& Gatica-Perez, 2014). The most common access used is social media, considering the data of Hootsuite Social Media, the number of social media users in Indonesia is estimated to reach 150 million (56\%). Furthermore, the number of mobile social media users has reached $48 \%$ of the total population. It is supported by the classification of social media user data based on research by Surahman \& Surjono (2017), as many as 100\% of respondents consisted of $90.3 \%$ BBM users (Blackberry Messenger), 93.5\% WhatsApp users, $80.6 \%$ Twitter users, and $77.4 \%$ Facebook users.

In effect, the potential of social media also brings negative impacts. For instance, is the distribution of false information (hoaxes) (Allcott, Gentzkow, \& Yu, 2019). Many experts argue that efforts to suppress misinformation through fact-checking become "failure" (Levin, 2017), and misinformation as a whole "becomes unstoppable" (Ghosh \& Scott, 2018). Therefore, social media management as a learning resource is deemed appropriate so that students obtain the truth of the information they access. Also, this management aims to realize Education 4.0. There are nine trends related to Education 4.0 including (1) times and places difference, (2) personalization of learning, (3) free choice, (4) project-based, (5) field experience, (6) data interpretation, (7) the exam will change completely, (8) learners' property and (9) the importance of assistance. Given these tendencies, it creates a new vision in learning, which is to improve students to learn not only the skills and knowledge required but also to be able to identify for learning these skills and knowledge (Setyosari, 2019).

Based on these reasons, the researcher probed online learning carried out using existing social media. The background for using social media is because this platform has become a virtual life for the community. In other words, in daily activities, the community is attached to social media, especially Youtube, Instagram, and WhatsApp. Those three social media platforms currently have the most significant users, especially in Indonesia. Besides, the culture of the Indonesian people tends to communicate frequently to each other. If social media can be explored in the learning process, it will slowly educate students and enrich new insights for themselves. On the contrary, if it is not optimized, it will impact morality; for instance, they absorb hoax or even the possibility of spreading it. Therefore, the social media that the researcher offers is used as a user-friendly digital learning resource so that students can learn without feeling burdened, whether in terms of device memory capacity or application installation costs. Moreover, the use of social media can be conducted anywhere and anytime, in schools, parks, even at home, and can also be used with various positions. 
Educational technology is a scientific root to facilitate learning (Januszewski \& Molenda, 2013). In facilitating the learning, the researcher examined relevant sources, especially related to social media. The method used is a literature review. The literature review attempts to integrate what others have done and uttered, criticize previous scientific works, build bridges between related topic areas, identify central issues in a study, or all of these (Cooper, 1998). The steps in conducting a literature review are (1) collecting data with related topics, themes, and characteristics, (2) analyzing relevant data and theories, (3) describing the results of the analysis, and (4) drawing conclusions. All processes or steps are carried out simultaneously.

In the first stage, the researcher collected data about social media, learning resources, and New Normal policy taken from books, websites, and related journals. Following data collection, the researcher analyzed the data obtained. Next, the researcher described the results of the data analysis that had been completed previously. Finally, the researcher drew conclusions from the study conducted. These sequences indeed contain limitations, such as data search, literature review, and many more (Fink, 2014).

In drawing conclusion, the researcher considered four aspects, namely (1) the current conditions or situations, (2) government policies that encourage the implementation of teaching and learning activities during the New Normal, (3) learning paradigms leading to constructivistic, and (4) the development of social media among students. Based on these four considerations, the researcher chose to conduct a study on social media Youtube, Instagram, and WhatsApp and expected that the use of social media could answer the existing learning needs.

\section{RESULTS AND DISCUSSION}

\section{Social Media and the New Normal Policy}

The New Normal Policy is a step taken by the government in the wake of recovery in various sectors, which initially declined due to a temporary shutdown. Education is one of the areas affected by this policy. With this policy, the government attempts to maximize the application of online learning for non-green zones and face-to-face learning (conducted in blended learning) for the green zone. It is performed to break the chain of the COVID-19 spread in severely affected areas. Therefore, teachers should maximize the existing digital learning resources to support the policy, especially the use of social media within.

Social media is used for socialization medium. Social media utilizes cellular-based technology and websites to create highly interactive platforms and enable people to communicate, share, collaborate, and modify the created content. Social media will create connections between users, ongoing interactions can be in the form of information exchange, news, problems, interaction, and many more (Nasution, 2020).

Research on social media use in learning shows that integrating social media in a learning and teaching environment may generate new forms of inquiry, communication, collaboration, work identity, or have positive cognitive, social, and emotional impacts (Greenhow \& Lewin, 2016). Based on Permana's (2018) research, social media can be used as a learning resource since it influences increasing the ability to think critically and creatively because the increase in motivation, critical thinking skills, and creative thinking abilities depend on its use. Based on the research description of Balakrishnan \& Gan (2016), the popularity of social media can encourage learning because of its wide popularity and the ability of options to enable creating virtual online learning groups, supporting the idea of sharing and promoting active interaction between students and teachers/lecturers can facilitate and encourage learning. However, the adoption of social media must be integrated into as part of the teaching curriculum, and educational 
learning needs to be performed only after a thorough, in-depth analysis in which clear guidelines relating to the use of the tool must be provided for them. Learning activities that utilize a variety of social media tools must also include every aspect to support inclusive students from various learning styles. Thus, social media used as a learning resource opens the possibility to increase one's competency according to his/her capacity (Kuswandi, Surahman, Thaariq, \& Muthmainnah, 2018; Surahman, Kuswandi, Wedi, \& Thaariq, 2019).

The researcher recommends using three social media as learning resources during the New Normal period, Youtube, Instagram, and Whatsapp. Considering the number of users, the three social media are the giants in Indonesia. Based on data gathered by Kata Data (Editorial Team, 2019), Youtube has $88 \%$ users, followed by WhatsApp with $83 \%$, and Instagram with $80 \%$. Thus, those three social media are considered appropriate to be managed as learning resources.

\section{The Use of Youtube as a Learning Resource}

YouTube has revolutionized online video by creating an interactive, personal, and fully customizable experience. This platform increases user creativity. YouTube requires video consumption and makes it private, interactive, and highly customizable. YouTube has revolutionized the online platform. Video streaming site depends on user-generated content and is open to anyone (Boer, Neal, \& Westlake, 2015).

Youtube is a social media that aims to share videos with other users. The use of Youtube can act as a learning resource for students. Youtube can build imagination, is interesting, and has the potential to build enjoyable learning (Berk, 2009). If Youtube is optimized as a learning resource, students will not only meet with their teachers and classmates but will also connect with students and teachers around the world. Moreover, YouTube provides free access to a large number of educational videos (Buzzetto-More, 2014). Users are allowed to download, view, and share video clips of various contents, including film clips, television shows, music, instructional videos, vlogs, or videoblogs, and amateur videos (DeWitt \& Dorothy, 2013). YouTube becomes social media when videos are shared, and comments and other forms of interaction occur on the site. This social media is effective for learning. Students may develop higherorder thinking skills such as decision making and problem-solving, as well as communicate and collaborate using social media (Bunus, 2010).

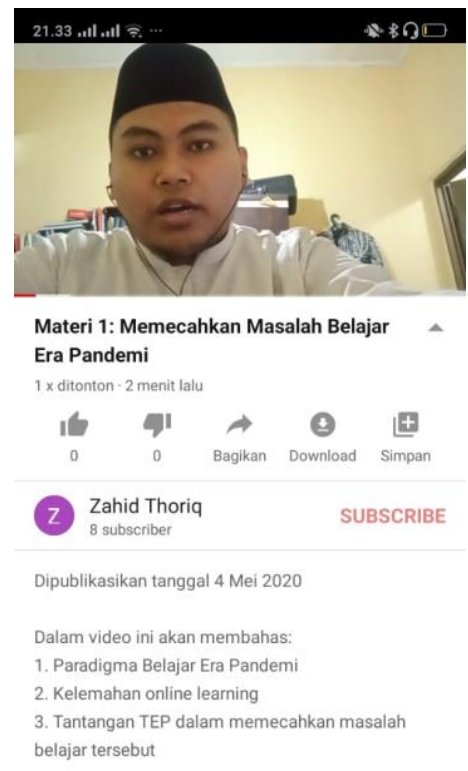

Figure 1. Example of Youtube as a Learning Resource

(Source: Private Documents) 
Several studies have revealed Youtube-assisted learning. Based on research by Iwantara, Sadia, \& Suma (2014), the use of Youtube could increase student motivation and learning skills because the media was easy to access. Besides, development research conducted by Iqbal, Latifah, \& Irwandani (2019) revealed that Youtube was used as an alternative medium for online learning for students, by taking into account that it must be accompanied by an appropriate approach. Research by Dewi \& Carniasih (2018) also showed that YouTube videos could re-display objects or events with a variety of changes (manipulation) as needed and could reach a broad audience in one presentation simultaneously in various places (distributive ability). Research by Yusri et al. showed the effectiveness of using YouTube in increasing learning motivation shown by the pre-test in the low category with a mean (M) of 33.74 and increased in the first cycle of student motivation in the high category with a mean (M) by 41.25 and the second cycle students' learning motivation was in the high category with a mean (M) of 48.28. (Yusri, Rosida, Jufri, \& Mantasiah, 2018). A study conducted by Walsh, O'Brien, \& Slattery (2019) discovered the effectiveness of using YouTube, as shown by the percentage of viewers during the learning process. Finally, research by Jackman (2019) revealed the success of Youtube as an e-resource in facilitating and guiding students in learning.

Some challenges related to the use of YouTube in learning expressed by Suryaman (in Setiadi, Azmi, \& Indrawadi, 2019) are found, namely: 1) Video availability, on the YouTube, several videos are only available within a specific time, so students or educators must consider the availability of the videos (Burke \& Snyder, 2008). 2) Quality of Content, for videos, to not be outdated, YouTube users, especially students and educators, must pay attention to the date of the video. Then, keep in mind the quality of the videos' content because the videos are often created individually without limits. Frequently, videos also violate the rules of appropriateness as they exhibit inappropriate or obscene videos (Buckley, Adelson, \& Agazio, 2009). 3) The search process, the next challenge is in the video search process. A video search can produce abundant video displays that confuse users in choosing a video to get appropriate information (Setiadi et al., 2019). Thus, the considerations in making Youtube content as a learning resource are (1) shortening the video duration with a brief, concise, and clear explanation because the shorter video will not be boring for students in the implementation of the learning process, (2) signaling or the emphasis in every material on Youtube because students prefer the clarity or conclusions of a material provided and (3) management of learning videos centered in one Youtube channel.

\section{The use of Instagram as a Learning Resource}

While other social media sites are declining in popularity, Instagram shows no decreased popularity and no signs of extinction anytime soon. Not only are users gathering in the site, but also marketers. With more marketing features and capabilities than ever before, Instagram is a platform that is a must for marketers because Instagram continues to add new information and perfect its functions (Miles, 2019).

Instagram is a social media that functions as a place to share photos (also videos) to other users. It makes this social media tends to attract many users because of the freedom to share photos. Similar to business, teachers should see this opportunity as a learning resource. 


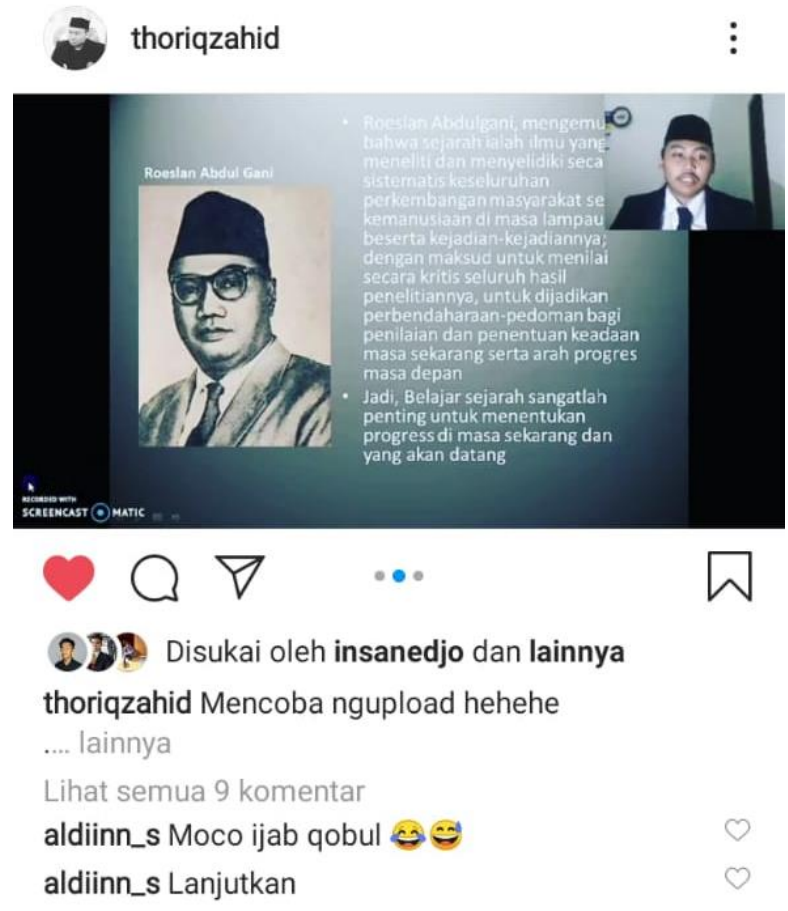

Figure 2. The Use of Instagram in learning

Source: Private Documents

Using Instagram as a learning resource is a potential that needs to be empowered. Instagram is a tool that can be installed on a mobile phone to support effective and efficient learning (Gonulal, 2019). However, despite its popularity, especially among adolescents, and the high potential for contextual visual data, only a few scientific studies have examined the role and function of Instagram in the learning context. In general, to support technology-based learning, it is recommended for such learning to be supported by technology such as smartphones, tablets, iPads, and other relevant digital devices, which can have an impact on the teaching and learning process. Instagram is a platform that supports technology-based learning (Azlan, Zakaria, \& Yunus, 2019).

Based on research conducted by Shazali, Shamsudin, \& Yunus (2019), Instagram facilitated the development of students' writing skills in terms of new vocabulary and increased motivation to learn. With simple media, someone will be more motivated to learn (Thaariq, Kuswandi, Diana, \& Shelinawati, 2019). Another study by Supiandi, Sari, \& Subarkah (2019) showed that the use of Instagram could increase the level of high-order thinking skills by an average of 94\%. Moreover, research by Manaroinsong (2019) discovered that Instagram could improve social skills, creativity skills, and technology literacy. In the study, it was also revealed that Instagram could practice higher-order thinking skills (Agrikaltarini, Susanto, \& Munir, 2019) and good writing skills (Kurniawan \& Kastuhandani, 2016). The use of Instagram can be used as a blended learning process, or in the context of learning outside the classroom (Sari \& Wahyudin, 2019). Further, Instagram content can practice good reading skills (Thomas \& Park, 2020). Obviously, a proper approach will allow Instagram appropriate to be used as a learning resource for students.

The challenges of using Instagram are like Youtube, thus, to minimize can be accomplished through (1) creating good content of images or videos attractively, (2) promoting content that is brief, packed, and clear, (3) organizing the management of each content, and (4) attractive learning approaches. If it can be accomplished, Instagram will be successfully used as a medium in delivering learning information. 


\section{The use of WhatsApp as a Learning Resource}

WhatsApp is a cross-platform instant messaging application for smartphones. It allows users to send and receive location information, images, videos, audio, and text messages in real-time to individuals and groups for free. Today, WhatsApp transfers more than 10 billion messages per day and is one of the most popular paid applications on all mobile platforms (Church \& De Oliveira, 2013). One of the application's unique features is the option to create groups and communicate within their limits. The creator of the group becomes the admin, a position that includes the privilege of adding and removing members without the concern of group members. Besides, all participants in the group enjoy equal rights. This application allows participants to receive notifications for each message sent or to mute the incoming alerts for 8 hours, a day, or a full week (Bouhnik \& Deshen, 2014).
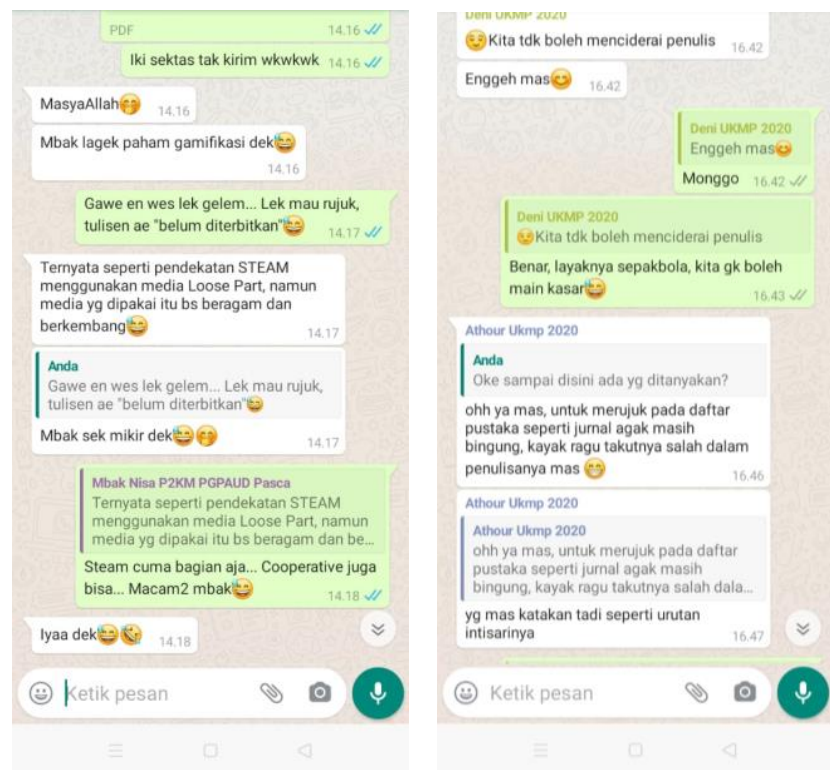

Figure 3 Learning using WhatsApp

Source: Private Documents

WhatsApp learning activities, which provide an easy-to-use interface supplemented with a news feed feature, allow students to be quickly notified about the community's updates and respond in time (Barhoumi, 2015). Furthermore, WhatsApp can also be used to represent user behavior. WhatsAppassisted learning is a recommended learning tool currently implemented at various levels of education to assist students to learn anytime and anywhere using their smartphone (Susanti, 2020). Therefore, Whatsapp can be used as a learning resource.

Based on research by Pangestika (2018), WhatsApp features that can be used to distribute learning information include Chat Groups, photos, videos, voice notes, and documents. The use of WhatsApp at the school is to communicate with family and friends, distribute information of announcements to share subject matter. Related to the output, based on research by Sa'diyah (2019), WhatsApp can be used as a medium to increase self-confidence. Also, other studies revealed that WhatsApp could be used to practice high-order thinking skills (Fauziah, 2019; Kartikawati \& Pratama, 2017; Sholihatin, Suana, \& Sesunan, 2019) and problem-solving (Suana, Raviany, \& Sesunan, 2019).

WhatsApp interaction in learning is elaborated in three main methods: teachers, student-peer, and students-content interaction. Therefore, it is divided into two challenges, device connectivity, and networked connectivity. In the device connectivity challenge, several studies revealed students' boredom about the strong dependence of wireless connectivity on the connections across campus, which forced 
some people to switch to their portable network devices or walk around schools to access the network. While in the networked connectivity challenge, students access WhatsApp through WiFi networks or private virtual networks. Such cellular connections often provide slower connectivity compared to institutional networks (Susilo, 2014). For that, what needs to be mended in developing learning through WhatsApp is the same as YouTube and Instagram, but some additions are (1) ensuring stable internet, (2) providing students time to respond, (3) using a scientific approach, and (4) maximizing learning resources such as e-books, e-magazines, or other resources to share with students.

\section{CONCLUSIONS AND RECOMMENDATIONS}

New Normal policy will have a major effect on the education sector. As explained above, the government emphasizes the optimization of full-online learning for non-green zones and face-to-face (blended learning) for green zones. The declining economy has led to community learning needs that are affordable for everyone, especially in terms of cost. Many learning applications are available, but from the aspect of affordability, it is very difficult for the middle to lower classes, particularly in accessing due to the cost of registration and the available devices. These problems are of interest to the researcher to examine social media that can be used as an affordable learning resource for everyone.

The conclusions that can be drawn regarding the use of Youtube as a learning resource are as follows: 1) Create interesting content. In this case, boring content can be produced in more interesting content. 2) The maximum duration of the video should be 3 minutes and delivered briefly, concisely, and clearly. 3) Use a scientific approach in the learning process. 4) In taking pictures, teachers need to imagine the layout of words or pictures because, during editing, the words or pictures are inserted into the video to give an explanation.

In the use of Instagram as a learning resource, several ways or stages can be carried out as follows: 1) Create interesting content, both images and short videos. 2) Content in the form of images should clearly describe what is written. 3) Producing video content is the same as Youtube; we recommend a maximum duration of 3 minutes 4 ) In writing content, use signaling for clarity of description in particular. 5) In making videos, use a scientific approach 6) Similar to Youtube, teachers need to imagine the layout when shooting the video.

Learning through WhatsApp as a learning resource, several ways or stages can be performed as follows: 1) Create a comfortable learning environment in general 2) Share learning resources, such as ebooks, e-modules, and so on through private or group chats. 3) Convey the material briefly, concisely, and clearly. 4) Invite students to discuss through chat. 5) Give time for students to respond in a private message. 6) Give time until 60 percent of students respond in group chats

Previous use of social media tends to be free for any purpose so that it has a potential if used as a learning resource. Many studies have discovered the success of social media as learning sources. Thus, as a learning technology expert, it is appropriate for the researcher to examine the adaptive learning resources assisted by social media. The impact of this use makes the teacher more creative in learning and students more comfortable in learning. This study is expected to be a reference in developing social media in learning so that the quality of education in the future will be better.

\section{REFERENCES}

Agrikaltarini, N. D. G., Susanto, S., \& Munir, A. (2019). Instagram and Students' Higher Order Thinking Skill of Creating. ANGLO-SAXON: Jurnal IImiah Program Studi Pendidikan Bahasa Inggris, 10(1), 01-14. 
Allcott, H., Braghieri, L., Eichmeyer, S., \& Gentzkow, M. (2019). The welfare effects of social media. National Bureau of Economic Research.

Allcott, H., Gentzkow, M., \& Yu, C. (2019). Trends in the diffusion of misinformation on social media. Research and Politics, 1-8. doi: doi.org/10.1177/2053168019848554

Aran, O., Biel, J.-I., \& Gatica-Perez, D. (2014). Broadcasting Oneself: Visual Discovery of Vlogging Styles. IEEE Transactions on Multimedia, 16(1), 201-215. doi: 10.1109/TMM.2013.2284893

Azlan, N. A. B., Zakaria, S. B., \& Yunus, M. M. (2019). Integrative Task-Based Learning: Developing Speaking Skill and Increase Motivation via Instagram. International Journal of Academic Research in Business and Social Sciences, 9(1), 620-636.

Balakrishnan, V., \& Gan, C. L. (2016). Students' learning styles and their effects on the use of social media technology for learning. Telematics and Informatics, 33(3), 808-821.

Barhoumi, C. (2015). The Effectiveness of WhatsApp Mobile Learning Activities Guided by Activity Theory on Students' Knowledge Management. CONTEMPORARY EDUCATIONAL TECHNOLOGY, 6(3), 18.

Berk, R. A. (2009). Multimedia teaching with video clips: TV, movies, YouTube, and mtvU in the college classroom. International Journal of Technology in Teaching \& Learning, 5(1).

Biagi, S. (2012). Media impact: An introduction to mass media. Cengage Learning.

Bingham, T., \& Conner, M. (2010). The new social learning: A guide to transforming organizations through social media. Berrett-Koehler Publishers.

Boer, S. de, Neal, J., \& Westlake, H. (2015). YouTube vlogging: The complete manual. West Midlands: Imagine Publishing Ltd.

Bouhnik, D., \& Deshen, M. (2014). WhatsApp Goes to School: Mobile Instant Messaging between Teachers and Students. Journal of Information Technology Education: Research, 13, 217-231. doi: $10.28945 / 2051$

Bozarth, J. (2010). Social media for trainers: Techniques for enhancing and extending learning. John Wiley \& Sons.

Buckley, K. M., Adelson, L. K., \& Agazio, J. G. (2009). Reducing the risks of wound consultation: Adding digital images to verbal reports. Journal of Wound Ostomy \& Continence Nursing, 36(2), 163170.

Bunus, P. (2010). The social network classroom. International Conference on Technology Enhanced Learning, 517-524. Springer.

Burke, S. C., \& Snyder, S. L. (2008). YouTube: An Innovative Learning Resource for College Health Education Courses. International Electronic Journal of Health Education, 11, 39-46.

Buzzetto-More, N. A. (2014). An examination of undergraduate student's perceptions and predilections of the use of YouTube in the teaching and learning process. Interdisciplinary Journal of ELearning and Learning Objects, 10(1), 17-32.

Church, K., \& De Oliveira, R. (2013). What's up with WhatsApp? Comparing mobile instant messaging behaviors with traditional SMS. Proceedings of the 15th international conference on Humancomputer interaction with mobile devices and services, 352-361.

Cooper, H. M. (1998). Synthesizing research: A guide for literature reviews (Vol. 2). London: Sage. 
Dewi, N. L. D. S., \& Carniasih, N. P. S. E. (2018). Pengaruh Media Pembelajaran Berbasis Youtube dalam Pembelajaran Tata Bahasa Inggris. Seminar Ilmiah Nasional Teknologi, Sains, dan Sosial Humaniora (SINTESA), 1(1).

DeWitt, A., \& Dorothy, N. (2013). The potential of Youtube for teaching and learning in the performing arts.

Etter, M., Ravasi, D., \& Colleoni, E. (2019). Social media and the formation of organizational reputation. Academy of Management Review, 44(1), 28-52.

Fauziah, K. (2019). Pengaruh model Group Investigation berbantu WhatsApp pada materi pencemaran lingkungan terhadap keterampilan berpikir kritis siswa. UIN Sunan Gunung Djati Bandung.

Fink, A. (2014). Conducting research literature reviews: From the internet to paper (Fourth edition). Thousand Oaks, California: SAGE.

Ghosh, D., \& Scott, B. (2018). Disinformation is becoming unstoppable. Accessed on June $16^{\text {th }}, 2020$, from Time website: http://time.com/5112847/facebook-fake-news-unstoppable/

Gischa, S. (2020). Jumlah Penduduk Indonesia 2020. Kompas. Taken from https://www.kompas.com/skola/read/2020/01/08/060000069/jumlah-penduduk-indonesia2020?page=all

Gonulal, T. (2019). The use of Instagram as a mobile-assisted language learning tool. Contemporary Educational Technology, 10(3), 309-323.

Greenhow, C., \& Lewin, C. (2016). Social media and education: Reconceptualizing the boundaries of formal and informal learning. Learning, media and technology, 41(1), 6-30.

Greenhow, C., \& Robelia, B. (2009). Old Communication, New Literacies: Social Network Sites as Social Learning Resources. Journal of Computer-Mediated Communication, 14(4), 1130-1161. doi: 10.1111/j.1083-6101.2009.01484.x

Iqbal, M., Latifah, S., \& Irwandani, I. (2019). Pengembangan Video Blog (Vlog) Channel Youtube Dengan Pendekatan Stem Sebagai Media Alternatif Pembelajaran Daring. Inovasi Pembangunan: Jurnal Kelitbangan, 7(2), 135-135.

Iwantara, I. W., Sadia, I. W., \& Suma, K. (2014). Pengaruh penggunaan media video youtube dalam pembelajaran IPA terhadap motivasi belajar dan pemahaman konsep siswa. Jurnal Pendidikan dan Pembelajaran IPA Indonesia, 4(1).

Jackman, W. M. (2019). YouTube usage in the university classroom: An argument for its pedagogical benefits. International journal of emerging technologies in learning (IJET), 14(09), 157-166.

Januszewski, A., \& Molenda, M. (2013). Educational technology: A definition with commentary. Routledge.

Jonassen, D., Spector, M. J., Driscoll, M., Merrill, M. D., van Merrienboer, J., \& Driscoll, M. P. (2008). Handbook of research on educational communications and technology: A project of the association for educational communications and technology. Routledge.

Karampiperis, P., \& Sampson, D. (2020). Adaptive Learning Resources Sequencing in Educational Hypermedia Systems. International Forum of Educational Technology \& Society, 21.

Kartikawati, S., \& Pratama, H. (2017). Pengaruh penggunaan whatsapp messenger sebagai mobile learning terintegrasi metode group investigation terhadap kemampuan berpikir kritis. JUPITER (Jurnal Pendidikan Teknik Elektro), 2(2), 33-38. 
Kemendikbud. (2020). Keterangan Pers: Penyelenggaraan Pembelajaran Tahun Ajaran dan Akademik Baru di Masa Pandemi COVID-19. Taken from https://youtu.be/-P9twRgPtSY

Kementerian Kesehatan. Panduan Pencegahan Dan Pengendalian Corona Virus Disease 2019 (COVID19) Di Tempat Kerja Perkantoran Dan Industri Dalam Mendukung Keberlangsungan Usaha Pada Situasi Pandemi. , Pub. L. No. HK.01.07/MENKES/328/2020 (2020).

Khan, B. H. (2005). Managing e-learning: Design, delivery, implementation, and evaluation. IGI Global.

Kilpatrick, A. L., Sengchanh, S., Namvongsa, V., \& Gray, A. Z. (2019). Medical Education in Lao People's Democratic Republic: The challenges students face in accessing learning resources. The Asia Pacific Scholar, 4(2), 39-47. doi: 10.29060/TAPS.2019-4-2/OA2034

Kurniawan, A., \& Kastuhandani, L. A. (2016). Utilizing Instagram for engaging students in their creative writing. Proceedings of Indonesia Technology Enhanced Language Learning, 4-7.

Kuswandi, D., Surahman, E., Thaariq, Z. Z. A., \& Muthmainnah, M. (2018). K-Means Clustering of Student Perceptions on Project-Based Learning Model Application. 2018 4th International Conference on Education and Technology (ICET), 9-12. IEEE.

Lau, K. H., Lam, T., Kam, B. H., Nkhoma, M., Richardson, J., \& Thomas, S. (2018). The role of textbook learning resources in e-learning: A taxonomic study. Computers \& Education, 118, 10-24. doi: 10.1016/j.compedu.2017.11.005

Levin, S. (2017). Facebook promised to tackle fake news. But the evidence shows it's not working. Accessed on June $16^{\text {th }}$, 2020, from The Guardian website: www.theguardian.com/technology/2017/may/16/facebook-fake-news-tools-not-working/

Manaroinsong, M. (2019). The use of instagram as mobile learning to support English cognitive learning process (Tesis). Universitas Islam Indonesia, Yogyakarta.

Miles, J. (2019). Instagram Power, Second Edition: Build Your Brand and Reach More Customers with Visual Influence (2nd ed.). Taken from https://www.books24x7.com/marc.asp?bookid=144448

Moore, J. L., Dickson-Deane, C., \& Galyen, K. (2011). e-Learning, online learning, and distance learning environments: Are they the same? The Internet and Higher Education, 14(2), 129-135.

Nasution, A. K. P. (2020). Integrasi Media Sosial dalam Pembelajaran Generasi Z. JTIP: Jurnal Teknologi Informasi dan Pendidikan, 13(1), 80-86.

Pangestika, N. L. (2018). Pengaruh Pemanfaatan Media Sosial WhatsApp Terhadap Penyebaran Informasi Pembelajaran di SMA Negeri 5 Depok (Thesis). UIN Syarif Hidayatullah, Jakarta.

Paquette, G. (2014). Technology-Based Instructional Design: Evolution and Major Trends. Dalam J. M. Spector, M. D. Merrill, J. Elen, \& M. J. Bishop (Ed.), Handbook of Research on Educational Communications and Technology (hlm. 661-671). doi: 10.1007/978-1-4614-3185-5_53

Permana, E. P. (2018). Pengaruh Media Sosial sebagai Sumber Belajar IPS Terhadap Motivasi Belajar, Kemampuan Berpikir Kritis dan Berpikir Kreatif Siswa Sekolah Dasar. PINUS: Jurnal Penelitian Inovasi Pembelajaran, 4(1), 54-59.

Praherdhiono, H., Setyosari, P., Degeng, I. N. S., Slamet, T. I., Surahman, E., Adi, E. P., ... Abidin, Z. (2019). Teori dan Implementasi Teknologi Pendidikan: Era Belajar Abad 21 dan Revolusi Industri 4.0. Seribu Bintang.

Pratomo, Y. (2019). APJII: Jumlah Pengguna Internet di Indonesia Tembus 171 Juta Jiwa. Kompas. Taken from https://tekno.kompas.com/read/2019/05/16/03260037/apjii-jumlah-penggunainternet-di-indonesia-tembus-171-juta-jiwa 
Putri, C. A. (2020). 3 Bulan Corona, 3 Juta Orang Kena PHK \& Dirumahkan. Accessed on June $15^{\text {th }}$, 2020, from https://www.cnbcindonesia.com/news/20200603193109-4-162890/3-bulan-corona3-juta-orang-kena-phk-dirumahkan

Sa'diyah, H. (2019). Upaya Menumbuhkan Self-Confidence Berbicara Bahasa Arab Mahasiswa melalui Grup WhatsApp. Al Mi'yar: Jurnal IImiah Pembelajaran Bahasa Arab dan Kebahasaaraban, 2(2), 149. doi: $10.35931 / a m . v 2 i 2.119$

Sari, F. M., \& Wahyudin, A. Y. (2019). Undergraduate Students' Perceptions Toward Blended Learning through Instagram in English for Business Class. International Journal of Language Education, 3(1), 64-73.

Setiadi, E. F., Azmi, A., \& Indrawadi, J. (2019). Youtube Sebagai Sumber Belajar Generasi Milenial. Journal of Civic Education, 2(4), 313-323.

Setiawan, H., \& Santoso, P. (2015). Model Optimalisasi Peluang Pemanfaatan Media Jejaring Sosial dalam Implementasi E-Governance di Indonesia. Seminar Nasional Informatika (SEMNASIF), 1(1).

Setyosari, P. (2019). Belajar Abad ke-21 dan Era Revolusi Industri 4.0. Dalam Teori dan Implementasi Teknologi Pendidikan: Era Belajar Abad 21 dan Revolusi Industri 4.0. Malang: Seribu Bintang.

Shazali, S., Shamsudin, Z. H., \& Yunus, M. M. (2019). Instagram: A platform to develop student's writing ability'. International Journal Of Academic Research In Business \& Social Science, 9(1), 88-98.

Sholihatin, T., Suana, W., \& Sesunan, F. (2019). Pengaruh Pemanfaatan Mobile Instant Messaging pada Pembelajaran Materi Hukum Newton terhadap Kemampuan Berpikir Tingkat Tinggi. Tarbawi: Jurnal IImu Pendidikan, 15(1), 1-10.

Suana, W., Raviany, M., \& Sesunan, F. (2019). Blended Learning Berbantuan Whatsapp: Pengaruhnya terhadap Kemampuan Berpikir Kritis dan Kemampuan Pemecahan Masalah. Gravity: Jurnal IImiah Penelitian dan Pembelajaran Fisika, 5(2).

Suparti, M., Juliardi, D., Rafsanjani, M. A., \& Praherdhiono, H. (2018). Determinant of Consumptive Behavior: Study on Accountancy Colleger. doi: 10.2991/icli-17.2018.34

Supiandi, U., Sari, S., \& Subarkah, C. Z. (2019). Enhancing Students Higher Order Thinking Skill through Instagram based Flipped Classroom Learning Model. 3rd Asian Education Symposium (AES 2018). Atlantis Press.

Surahman, E., Kuswandi, D., Wedi, A., \& Thaariq, Z. Z. A. (2019). Students' Perception of Project-Based Learning Model in Blended Learning Mode Using Sipejar. International Conference on Education Technology (ICOET 2019). Atlantis Press.

Surahman, E., Sulthoni, S., Ulfa, S., Husna, A., Ramdiana, H., Thaariq, Z. Z. A., ... Qolbi, M. S. (2020). Pelatihan Micro Learning Object Berbasis TPACK bagi Guru-Guru SMA di Garut. Abdimas Pedagogi: Jurnal IImiah Pengabdian kepada Masyarakat, 3(1), 1-14.

Surahman, E., \& Surjono, H. D. (2017). Pengembangan adaptive mobile learning pada mata pelajaran biologi SMA sebagai upaya mendukung proses blended learning. Jurnal Inovasi Teknologi Pendidikan, 4(1), 26-37.

Susanti, S. (2020). The Use of WhatsApp in Reading Lesson at the STMIK Pontianak, West Kalimantan, Indonesia. MIMBAR PENDIDIKAN, 5(1), 57-74.

Susilaningsih, S., Praherdhiono, H., Adi, E. P., \& Nindigraha, N. (2018). Analysis of Climate Strengthening and Learning Skills through Flipped Classroom. 1st International Conference on Early Childhood and Primary Education (ECPE 2018). Atlantis Press. 
Susilo, A. (2014). Using Facebook and WhatsApp to leverage learner participation and transform pedagogy at the Open University of Indonesia. Jurnal Pendidikan Terbuka Dan Jarak Jauh, 15(2), 63-80.

Thaariq, Z. Z. A., Kuswandi, D., Diana, R. C., \& Shelinawati, U. (2019). Factors that Influence Outstanding Student (Mawapres) in Learning Motivation. JPP (Jurnal Pendidikan dan Pembelajaran), 26(2), 60-64.

Thomas, K., \& Park, S. (2020). Integrating Instagram into the Curriculum of a Japanese Freshmen English Communication Course for Reading and Writing Activities. CELE JOURNAL, 28.

Tim Redaksi. (2019). Youtube, Medsos No. 1 di Indonesia. Accessed on June $16^{\text {th }}, 2020$, from Kata Data website: https://katadata.co.id/infografik/2019/03/06/youtube-medsos-no-1-di-indonesia

Walsh, J. N., O'Brien, M. P., \& Slattery, D. M. (2019). Video Viewing Patterns Using Different Teaching Treatments: A Case Study Using YouTube Analytics. Research in Education and Learning Innovation Archives, (22), 78. doi: 10.7203/realia.22.15389

Wikipedia. (2020). COVID-19 pandemic in Indonesia. Accessed on June 15th, 2020, from https://en.wikipedia.org/wiki/COVID-19_pandemic_in_Indonesia

Yusri, Y., Rosida, A., Jufri, J., \& Mantasiah, R. (2018). Efektivitas Penggunaan Media Youtube Berbasis Various Approaches dalam Meningkatkan Motivasi Belajar Bahasa Inggris. Eralingua: Jurnal Pendidikan Bahasa Asing dan Sastra, 2(2).

How to Cite: Thaariq, Z. Z. A. (2020). The use of social media as learning resources to support the new normal. Teknodika, 18 (2), 80 - 93. DOI: https://doi.org/10.20961/teknodika.v18i2.42181 